\title{
Debt in Islam: Survey in Consumer Perception
}

\author{
Hainnur Aqma Rahim, Salimah Yahaya, Khalijah Mohd Nor, Amirah \\ Hazimah Borhanordin
}

To Link this Article: http://dx.doi.org/10.6007/IJARBSS/v11-i2/8659

DOI:10.6007/IJARBSS/v11-i2/8659

Received: 07 December 2020, Revised: 04 January 2021, Accepted: 20 January 2021

Published Online: 08 February 2021

In-Text Citation: (Rahim et al., 2021)

To Cite this Article: Rahim, H. A., Yahaya, S., Nor, K. M., \& Borhanordin, A. H. (2021). Debt in Islam: Survey in Consumer Perception. International Journal of Academic Research in Business and Social Sciences, 11(2), 165-176.

\section{Copyright: (c) 2021 The Author(s)}

Published by Human Resource Management Academic Research Society (www.hrmars.com)

This article is published under the Creative Commons Attribution (CC BY 4.0) license. Anyone may reproduce, distribute, translate and create derivative works of this article (for both commercial and non-commercial purposes), subject to full attribution to the original publication and authors. The full terms of this license may be seen

at: http://creativecommons.org/licences/by/4.0/legalcode

Vol. 11, No. 2, 2021, Pg. 165 - 176

Full Terms \& Conditions of access and use can be found at http://hrmars.com/index.php/pages/detail/publication-ethics 


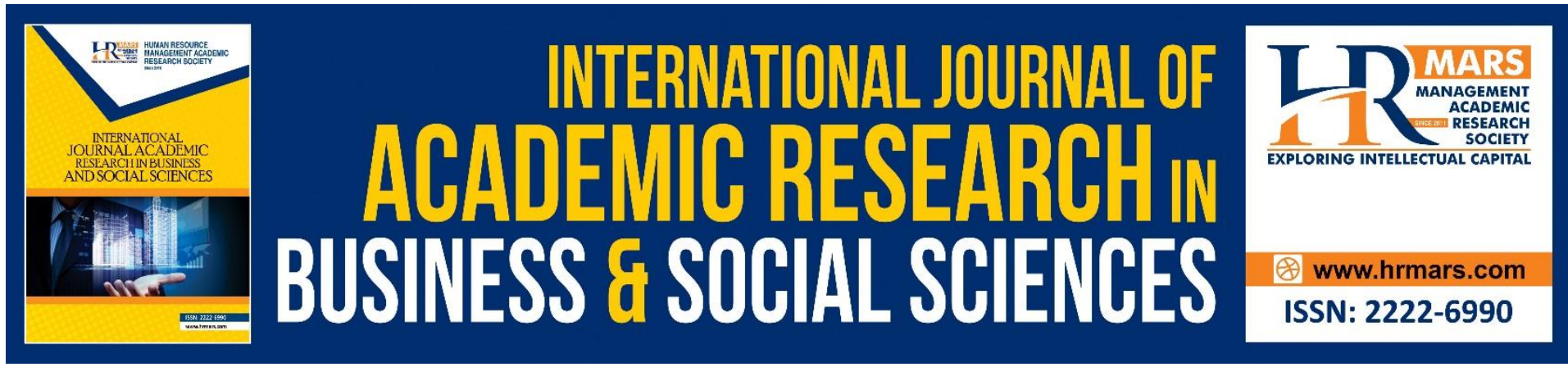

\title{
Debt in Islam: Survey in Consumer Perception
}

\author{
Hainnur Aqma Rahim \\ Center for Islamic Philantrophy \& Social Finance (CIPSF), Universiti Teknologi MARA (UiTM) \\ Cawangan Melaka Km 26 Jalan Lendu, 78000 Alor Gajah, Melaka, MALAYSIA \\ Email: hainnuraqma@uitm.edu.my
}

\section{Salimah Yahaya}

Academy Contemporay of Islamic Studies, Universiti Teknologi MARA Cawangan

Terengganu, Sura Hujung, 23000 Dungun, Terengganu, MALAYSIA

Email: sal_hasa@yahoo.com

\begin{abstract}
Khalijah Mohd Nor
Faculty of Business and Management, Universiti Teknologi MARA Cawangan Melaka, Km 26 Jalan Lendu, 78000 Alor Gajah, Melaka, MALAYSIA

Email: khalijah904@uitm.edu.my, amirahhazimah@uitm.edu.my
\end{abstract}

\author{
Amirah Hazimah Borhanordin \\ Faculty of Business and Management, Universiti Teknologi Mara (UiTM) Cawangan Melaka, \\ 110, Off Jalan Hang Tuah, 75350 Melaka \\ Email: amirahhazimah@uitm.edu.my
}

\begin{abstract}
Consumption is closely related to planning household expenses to purchase goods and services to meet the demands of living needs. The economic climate has now shown the tendency of society to over spending which is difficult to control leading to high debt. The household debt issue is seen as a crisis with great impact in influencing the macroeconomic stability level of a country. The negative effects of consumption activities in this modern economy cannot be healed unless the Muslim community return to the true understanding of Islamic consumption concept. This study aimed to examine the concept of debt in Islamic consumerism as household debt also serves as an injection to consumption. This study used descriptive analysis on the consumerism concept according to Islam and its relation to debt by referring to the Quran, hadith and literature review. Secondary data were taken from websites and research papers. The findings of the study showed that the consumption theory in the Islamic economy is able to provide a good and practical way of spending without causing inflation and dissipate that will inevitably lead to debt problems.
\end{abstract}

Keywords: Consumers, Consumer Behavior, Debt, Consumption 


\section{Introduction}

Debt management is one of the tools in Islamic property management. Debt of the deceased must be settled first before the will and faraid matters are implemented. In this regard, all the "ulama have agreed that debts should be given priority before wills and faraid (Jusoh, Awang \& Yusoff, 2011). Islam is a comprehensive religion that covers all aspects in providing law and guidance with certain conditions including matters involving debts.

Therefore, the Muslim Malays should consider debt as one of the options used to meet the basic needs if desperate and not a habit to satisfy the desire. However, until now, the debt issue still exists, causing problems among the Muslim community in Malaysia. This conflict has actually arisen for a long time since the British colonial era which has been emphasized by the following statement:

"The Malays fell into debts because of the tendency to be extravagant and because of the lack habits of thrift"

This statement can be proved by the debt crisis plaguing the Muslim Malay majority, resulting in bankruptcy. In 2006, the Deputy Minister of Prime Minister's Department revealed that a total of 13,590 Malays have been declared bankrupt which surpassed Chinese (5,735 people), Indians (1,165 people) and others (431 people) (Jusoh, Awang \& Yusoff, 2011). Therefore, consumer education is necessary so that prudent financial management can be implemented. Realizing this fact, it should be questioned what is the point of view of Tasawur on debt? What is the concept of debt based on Islamic consumerism? Thus, this study is significant for Muslim consumers particularly who deem debt as the last option to their financial problems. Therefore, this study aimed to examine debt based on the Islamic consumerism using descriptive analysis by referring to the Quran, hadith and literature review. Secondary data were taken from websites and academic journals. This study is limited to discussing consumer debt involving households only. The discussion of this paper is divided into four main themes consisting of definition of debt, concept of debt in relation to Tasawur, principles of Islamic consumerism, and concept of debt based on Islamic consumerism.

\section{Definition of Debt}

From an etymological point of view, debt or al-qard means cut. Debt is also defined as loans and prices of goods. In this context, debt is considered as future liability incurred on a person either in the form of money or others. In terms of terminology, debt refers to the granting of mithly property by an individual to another individual with the intention that the individual will repay it (Zakaria et al., 2012).

Based on Islamic perspective, debt is classified as one of the contracts in Islamic muamalah affairs that is required and seen as a practice of helping which is highly organized by Islam as long as it follows the Islamic path (Alidaniah, Ahmad \& Noor, 2015). Tahir and Ahmad (2009) used the terms 'al-qard', 'al-dayn' and 'al-i'arah' to explain the concept of debt and loan. In essence, these three terms support the meaning of debt but there is a slight difference in the definition of al-qard of which debt not involving the exchange of trading and requires the return of other goods of similar or equal value (Tahir \& Ahmad, 2009). On the other hand, aldayn refers to debt that involves the exchange of sales and purchases with other goods of equal value, while al-i'arah is a debt or loan that requires the return of all borrowed goods or the same goods. Al-dayn can also be used with the meaning of an act that leaves some of its rights to others. Also, debt is everything that is not in front of one's eyes. In contrast, debt in 
the conventional context clearly has no element of banning usury in every debt contract formed (Alidaniah, Ahmad \& Noor, 2015).

\title{
Concept of Debt based on Tasawur
}

The discussion of debt analysis in this study is based on the perspective of Tasawur. The basic elements of Tasawur are formed from three factors, namely Allah SWT as the creator, man as a creature and the universe as a creature (Hanapi, 2014). Furthermore, Al-Zyan (1982: 11-12) highlighted that the formation of Tasawur is based on the source of revelation of Allah SWT, the concept of ad-din (religion) which is inseparable from life and balance between material and spiritual aspects (Hanapi, 2014: 13). Tasawur is formed from Islamic epistemology which uses the Quran, Hadith, ljmak and Qiyas as sources of references.

Islam has given the obligation in debt, focusing on those who really need it but not for lavish expenses. In the Quran, the obligation of debt has been mentioned in Al-Baqarah verse 282, which means:

\begin{abstract}
"Believers! Whenever you contract a debt from one another for a known term, commit it to writing. Let a scribe write it down between you justly, and the scribe may not refuse to write it down according to what Allah has taught him; so let him write, and let the debtor dictate; and let him fear Allah, his Lord, and curtail no part of it.
\end{abstract}

The concept of debt in Tasawur needs to be evaluated from the two parties involved in the debt contract, namely creditors and debtors.

\section{Debtors}

Based on the debt concept in Tasawur, those who should be in debt are known as Al-Gharimi (al-Qardawi, 2002). Al-Gharimin is divided into two types, namely indebted person for own needs and indebted person for helping those in distress and desperation. According to Imam al-Syatibi, every individual should take care of life, religion, intellect, property and lineage (Razak \& Dali, 2012). In addition, the indebted individual must not own property at a sufficient rate (kifayah limit). The basic requirements taken into account in determining the kifayah limit covers several aspects, for example the Selangor Zakat Board takes into account six aspects, such as protection, food, clothing, medicine, education and transportation. This also means that borrowers of the National Higher Education Fund Loan (PTPTN) having no source of funds to settle their education loans can be included in al-Gharimin group (Tahir \& Yusof, 2014). It is certain that those who are allowed to be in debt are those who bear burden, poor and affected by disasters which could help them surviving (Rahim, Sulaiman \& Razzak, 2012).

\section{Purpose of Debtors and Creditors}

From the context of human relationship with Allah SWT (habluminallah), creditors should ease the burden of individuals who are in need and must not take advantage on the difficulties faced by the debtors for the sake of seeking special reward from Allah SWT. This is in line with the main principle of the debt concept in Islam, which is ta'awun (helping) fellow individuals who are in trouble (Sulaiman, 2011). Rasulullah SAW said:

"Whoever relieves a believer's distress of the distressful aspects of this world, Allah will rescue him from a difficulty of the difficulties of the Hereafter. Whoever alleviates [the situation 
of] one in dire straits who cannot repay his debt, Allah will alleviate his lot in both this world and in the Hereafter". (Narrated by Abu Dawud dan Tirmidzi).

The above hadith clearly describes the advantages of individuals who can relieve the hardships of other individuals by giving debts, and creditors should ensure the purpose of the debtor must not be contrary to Islamic law. The law of giving debts to the debtors will be makruh if the debts given are for lavish life (Rahim, Sulaiman \& Razzak, 2012). In addition, the purpose of performing a debt contract must be in line with Islamic law. Therefore, debt should meet the needs of life in line with the demands of Allah SWT, and debt should be made to aid others achieve the pleasure of Allah SWT. In addition, the purpose of borrowing and giving debts should be based on the importance of maqasid syariah, namely din (religion), nafs (soul), nasl (lineage), mal (property) and aql (intellect).

For example, al-Qardawi (2002) justified that Islam allows debt for things that do not lead to dissipate, exaggeration and lavish which are contrary to the command of Allah SWT (Raziah Md Tahir and Syarifah Md Yusof, 2014). This can be explained by

"And render to the kindred their due rights, as (also) to those in want, and to the wayfarer: But squander not (your wealth) in the manner of a spendthrift. Verily spendthrifts are brothers of the Evil Ones; and the Evil One is to his Lord (himself) ungrateful." (Al-Israa': 26 - 27).

Based on the above verses, expenses need to be controlled to avoid dissipation and debts, resulting in bankruptcy.

\section{Behaviour of Debtors and Creditors}

From the context of relationship among human (habluminannas), creditors and debtors must be trustworthy and honest as an aqad or agreement that could aid each other, love and strengthen the faith between those who in need and those who could help. This can be explained further as follows:

"If you are on a journey and cannot find a scribe, pledge your goods (against the Loan); and if one trusts the other, then let him who is trusted deliver the thing entrusted, and have fear of God, his Lord. Do not suppress any evidence, for he who conceals evidence is sinful of heart; and God is aware of all you do."(Al-Baqarah : 283)

In fact, the good attitude when paying or asking for debts is also demanded in Islam it will further strengthen the relationship between debtors and creditors. As a sign of gratitude and appreciation, debtors should have good manner to compensate the kindness of creditors to give the debt. Rasulullah SAW said:

"The Prophet owed a camel of a certain age to a man who came to demand it back. The Prophet ordered his companions to give him. They looked for a camel of the same age but found nothing but a camel one year older. The Prophet told them to give it to him. The man said, "You have paid me in full, may Allah pay you 


\section{in full." The Prophet said, "The best amongst you is he who pays his debts in the most handsome manner".}

(Narrated by Abu Hurairah R.A)

The above hadith explains that paying off debt more than what he owes indicates the good attitude of the debtor. However, the surplus cannot be specified in initial contract as it will become usury. The prohibition of usury has been explained in the Quran as follows:

"Allah has allowed trade and forbidden usury."(Surah alBaqarah : 275)

Therefore, surplus is considered as gift or reward after settling the debt. This attitude is often practiced by the prophet when paying off the debt. Creditors also should be friendly and not persuasive when claiming debts (Jusoh, Awang, Yusoff, 2011). The kindness of the creditor can also be rewarded by praying for his well-being as performed by Rasulullah SAW:

"The Prophet borrowed forty thousand from me, then some wealth came to him, and he paid me back and said: May Allah bless your family and your wealth for you: the reward for lending is praise and repayment. (Narrated by Isla'il bin Ibrahim bin 'Abdullah bin Abi Rabiah)

Based on the above hadith, praying for the well-being of creditors could strengthen the relationship between creditors and debtors. In addition, claiming debt in a good manner is a mahmudah trait included in Islamic debt muamalat. Rasulullah SAW said:

"May Allah's mercy be on him who is lenient in his buying, selling, and in demanding back his money" (Narrated by Muhammad bin al-Munkadir, from Jabir bin Abdullah R.A)

The above hadith encourages creditors to be generous when claiming debts without burdening the debtors to be rewarded with Allah's mercy.

\section{Obligation on Paying off Debts}

The obligation to pay off debts involves the relationships between God and human (habluminnallah) and human and human and natural resources (habluminannas). In Islam, debt repayment is compulsory and it is the responsibility of the debtor to pay off his debt according to a predetermined period. If the debtor fails to pay off the debt, it will lead to hatred and humiliation and thus affect society if good relationship among human is not maintained due to debt. A moralize debtor will always keep his promise as such attitude is one of the traits of siddiq (true). In fact, Islam requires the heir of the debtor to pay off the debtor's debt if the debtor passed away. Hence, it is crucial to pay off debt while still alive. As said by the Prophet SAW:

"Whoever dies free of these three, arrogance, usurping the spoils, and debt, he will enter Paradise" (Narrated by Ibnu Majah no. 2412. Syaikh Al Albani).

Furthermore, the debtor who dies before paying off his debt during his lifetime, the debt must be settled using the property he left before distributing it to his heirs. Rasulullah SAW always keeps his promise while paying off his debts and never once postponed payment since before 
he was appointed as the Messenger. A person can be considered a hypocrite if he does not keep his promise. Despite the obligation in debt repayment, Islam still gives flexibility to debtors. The necessity in deferring the debt payment when the debtor is facing in life crisis can be explained in the Quran:

"And if the debtor is in want, give him time until his circumstances improve; but if you forego (the debt) as charity, that will be to your good, if you really understand." (Al-Baqarah: 280)

The sentences explained about the compulsory of creditors in delaying his/her debts in difficulty situation to pay the debts until the debtors can do so. In other hand, Allah SWT always suggest to disregard all or half of the debts for the charity or value it as a good example and will be promised for many "pahala". This matter has been explained by Allah SWT in AlBaqarah verse 280 , which means:

"If you always donate that debts (to the debtors), it is better for you to know (a big "pahala" will you gain in the future)" (AlBaqarah: 280)

According to the above sentence, Allah SWT stated that, if the creditors donate all or half of his/her debts it is much better to know that a big reward will be gained to the creditors. In addition, Islam allows the creditors to give an ample time to the debtors that having the difficult situation to pay his/her debts. The best way is, the creditors in his/her open heart to donate all or half of the debts in order to gain "pahala" from Allah SWT.

\section{The Principle of Consumerism in Islam}

An education of consumerism must be cultivated among all consumers, so that they can manage their financial efficiently and free from the extreme debts. Consumerism concept in Islam has taken from Tasawur Islam as the basic as a different human behaviour with the common consumerism concept. This is because, the Islam consumerism concept recognize the consumer as an Islamic man and to ensure the goal of spiritual is the main goal as the material goal is focusing on the concept of product and services (Friedman, 1979; Chapra, 1995; El-Ashker, Abdel-Fattah \& Wilson, 2006).

Contradict, the consumer concept usually recognizes a human as an economic creature (homoeconomicus) that focus on income usage for the the satisfaction (Bakar, 2003:53-54). Islam consumerism put the needs as the main goal from the desire (Rahim, Sulaiman \& Razzak, 2012). In Islam, the hierachy of needs are focusing on consumerism guidance which is dhahruriyyat, tahsiniyyat dan kamaliyyat.

Hence, the main choice can be divided into six types of products. There are needs of life, basic needs product, the efficiency product, the comfort product, luxury products and dangerous products. (Hassan \& Ahmad: 2005: 80-82).

If look thoroughly in deeper, the Islam consumerism principle is based on two elements. It is general consumerism principle and the measure of consumerism principle. Under the general 
consumerism, the behaviour of human economic in Islam framework is based on three principles. There are the believe of the hereafter, the achievement concept and wealth concept. Under the consumerism measure principle, it is lined by several principles including truth or right, cleanliness or purifying, moderation, benefits and problems, spiritual and moral. All these principles will be explained in details as below (Hassan \& Ahmad, 2005:7479):

a) Truth or Right $\rightarrow$ This principle will allow the consumerism must get the bless from Allah SWT ain (zat), is the way or reason of that consumerism. Same goes to halal product will be non-halal if the usage of that product is contradict from the syarak and not the intention to Allah SWT because the usage of that product is not based on the right. The main reason is truth or right only for the God of Allah SWT.

b) Cleanliness or Purifying $\rightarrow$ This principle is stressed on the clean, purifying of product usage, good, usable and can be eaten (if there is food). The non-halal, dirty, mixed with excrement, bad or stink with stale are categorized as a dangerous products and cannot be used or eaten. Gold and silk are also not allowed to be worn by men. Gold and silver also cannot be used as a food container.

c) Moderation $\rightarrow$ This principle is stressed on the moderation of usage and expenses and not be overwhelming and can manage the needs. The usage of overwhelming is not a good behaviour and it refer to israf (extravagant) and tabthir.

d) Benefits $\rightarrow$ This principle is stressed on the gift from the God which is Allah SWT which is halal of the product usage and it is benefit to the society. The usage of non-halal products is allowed for dharurat (if there is threaten of our life) but must not too outrageous.

e) Spiritual and moral $\rightarrow$ This principle is stressed on the ethics concepts, politeness and have a good behaviour by excluding the bad manners. Every person must always be thankful to the God, zikr and think before use something and always be patience in using the products.

\section{The Concept of Debt in Islam}

A debt is one of the functions need to implemented in economy. The allocation and pattern of the expenses of is influence by the types of products and the power of buying by consumers. The importance of debt in social and economy is needed by Islam. Rationally, this principle is applied in Islam as a debt is not to be used as an issue and spread by the Muslim itself. In the concept of Islam consumerism, it forms and follows by the 'tasawur' that depends on the epistemology in using of Al-Quran, Hadith, Lima' Ulama and Qias as a references.

\section{A group of al-Gharimin that allow to go into debt}

In order to take a consideration of creditor and a debtor, the concept of of Islam in consumerism is emphasized by the relationship of human and God which ish Allah SWT (hablumminallah), human with human and a nature resources (hablumminannas). According to the debt concept in Islam consumerism, the eligible individuals indebted are from the group of al-Gharimin. This is because, al-Gharimin is described as an indebted group. This is a basic need and not to be wasted. The qualifications of al-Gharimin to be in debt is based on the Islam usage context under the achievement of Islam and the principle of moderation as well as usage and right. Briefly, the debtor that get the sources from the debt must use the 
way of Allah SWT, 'halal' and clean, free from any wrong of 'syarak', as the usage not to extravagant and luxurious.

\section{Needs and Purposes of Creditors and Debtors}

Other than that, the concept of debt in Islam consumerism also look at to the need and purpose of debtors and creditors. All the intention must via Allah SWT. The need and purpose of debtors and creditors must be under the general principle of the usage. The principle must be under Islam measure. For example, the creditors give a debt to put the trust of hereafter. With the measurement the day of hereafter, the creditors will give debts not only for rewards to the debtors but give debts with the concept of $t a^{\prime}$ awun to get the rewards from Allah SWT. In that reason, the creditors need a debt, must be reasoned to get the products with the permission from Allah SWT. The pure/good products must give benefits to ourselves and to the society.

\section{The behaviour of creditors and debtors.}

The behaviour of creditors and debtors must follow the principle of soul and mora under the usage measurement principle. This principle needs to cultivate creditors and debtors to be grateful with the grace but must think also to the other individuals that not have a chance to from Allah SWT. Every usage but mention the name of Allah SWT. Before begin with the usage the individual must have a patience with the gifted from Allah SWT. The ravenous is not allowed in Islam. All the usage that receives from the debts must synchronize with the value of spirituality and moral. According to the analysis, the principle of debts and the principle of usage Islam, one concept in Islam usage can be developed and showed via figure 5.1 as below: 


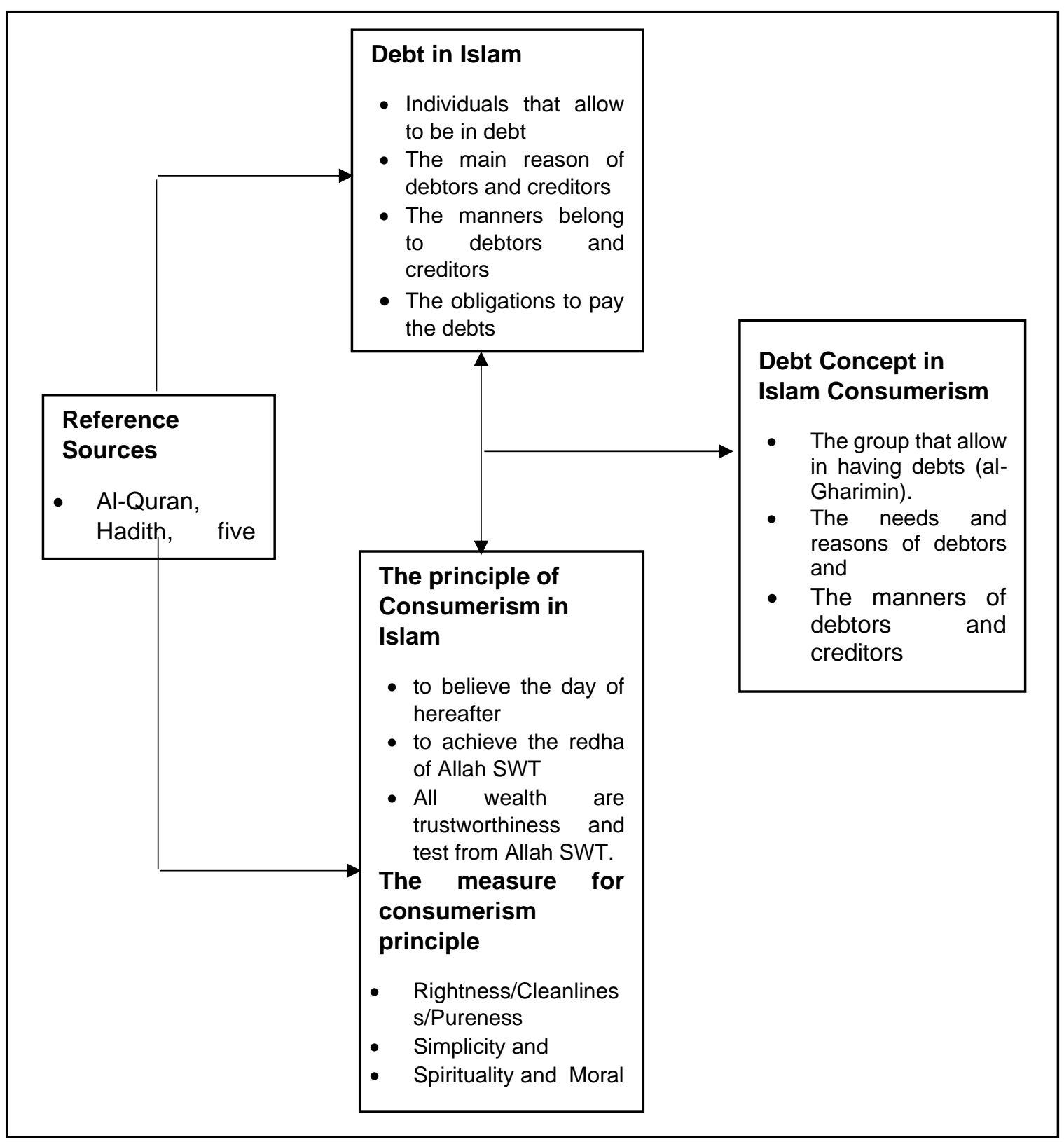

Figure 5.1 The Framework of Debt Concept in Islam Consumerism

\section{Conclusion}

Based on the Muslim consumer's behaviour that consist of the above matter, the Muslim consumer need to know how to develop the consumer's behaviour. They need to know how to allocate the income with the knowledge of economy consumerism. This is because, in the conventional economy, the concept of buying is depending on the choices with the maximum satisfaction. Hence, the value of products and services in the principle of economy in Islam, is based on the target of the individual that aim for al-falah, devotion or the responsibility as a khalifah. From this approach, the principle of consumerism of economy in Islam aid the society and government to overcome the unhealthy consumerism and unbalanced of expenses. This is good as a guidance to the Muslim as a worship to Allah SWT toward the usage of daily products and services. Therefore, the debt problems among household consumer can be solved if the concept of Islam consumerism is practiced by the Muslim. 


\section{References}

Ashker, F. A., \& Wilson, R. (2006), Islamic economics: a short history, edition, 2006, pp.32, published by Koninklijke Brill NV, Leiden, The Netherlands.

Al-Tabari, J. M. (1992). Jami' al-Bayan fi Ta'awil al-Qu'ran. Beirut: Dar al-Kutub al-Ilmiah

Al-Qaradawi, Y. (2002). Hukum zakat. (Translation) Salman Harun, Didin Hafidhuddin \& Hasanuddin. Bogor, Indonesia: Pustaka Litera AntarNusa.

Al-Zayn, A. S. (1982). Al-Islam wa Idiyulujiyyah al-Insan. Beirut, Lubnan : Dar al-Kitab alLubnaniy.

Chapra, U. M. (1995), Islam and the Economic Challenge, The Islamic Foundation and the International Institute of Islamic Thought, edition: 1995, pp.20-29

Fayyumi, M. A. (2000). al-Misbah al-Munir. Kaherah: Dar al-Hadis.

Friedman, M. (1979). The Methodology of Positive Economics, in F. Hahn and M. Hollis, Philosophy and Economic Theory (1979: 19).

Tahir, H. M., \& Ahmad, S. (2009). Aplikasi fiqh muamalat dalam sistem kewangan Islam. Pusat Penerbitan Universiti (UPENA), UiTM.

Bakar, M. H. A. (2003) Apa itu ekonomi islam. Pahang. PTS Publication \& Distributors Sdn Bhd. Hanapi, M. S. (2014). Tasawur Islam dan Pembangunan. Kuala Lumpur. Dewan Bahasa dan Pustaka

Yasin, M. S. H. (1992), Akhlak dan Tasawuf, Kuala Lumpur, Mas'adah (M) Sdn Bhd. Hal. 468.

Jusoh, M. K. A., Awang, M. D., \& Yusoff, A. N. M. (2011). Akhlak mahmudah dalam pengurusan hutang islam : kajian awalan terhadap kefahaman kakitangan awam di uitm pahang. Persidangan 5th Isdev International Islamic Development Management (IDMAC 2011). Universiti Sains Malaysia. 13-14 Disember 2011.

Rahim, N. M. Z. A., Suliaman, I., \& Razzak, M. A. (2012). Kesempitan hidup penghutang: analisis ayat 280 surah al-baqarah. Proceedings: The $2^{\text {nd }}$ Annual International Qur'anic Conference.

Alidaniah, N. A. R., Ahmad, S., \& Noor, M. A. M. (2015). Budaya Hutang isi rumah mengikut etnik: halal haram hutang dalam islam. Persidangan Kebangsaan Ekonomi dan Kewangan Islam 2015.

Sakirullah, A., Mohd, H., \& Khairuldin, W. (2019). Civil Marriage In The Light Of Figh AlMaqaasid, Nigeria As A Case Study. International Journal Of Academic Research In Business And Social Sciences, 9(4).

Abdul, N., Khairuldin, W. M. K. F., \& Ismail, M. S. (2020). Fiqh Muamalat Islam: Hukum Dalam Sistem Jual Beli Atas Talian (E-Dagang) Dari Sudut Pandangan Fuqaha [Islamic Muamalat Of Fiqh: Legal System In Selling Online (E-Commerce) From The Fuqaha Islamic View]. AL-QIYAM International Social Science and Humanities Journal, 2(1), 24-35.

Embong, A. H., Yasin, M. F. M., \& Khairuldin, W. M. K. F. W. (2019). Introduction To Technologised Quranic Learning In Ulul Albab Quranic Studio. Technology, 10(3), 33233335.

Mokhtar, W. K. A. W., Khairuldin, W. M. K. F. W., Ibrahim, A., \& Embong, A. H. (2018). Al'Aqīdaț Al-Ṣahīḥat as the Essential Element of Worldview of Development Integrity and Accountability. International Journal Of Academic Research In Business And Social Sciences, 8(11), 328-337.

Razak, N. A., \& Dali, S. Z. A. (2012). Perbezaan analisis kepenggunaan menurut ekonomi konvensional dan ekonomi islam. Prosiding PERKEM 2, 1461-1470.

Tahir, R. M., \& Yusof, S. M. (2014). Status individu muflis dalam asnaf al-Gharimin. Journal of Business and Technopreneurship, 4(3), 477-494. 
Zakaria, R. H., Kader, R. A., Jaafar, N. I. M., \& Marican, S. (2012). Burgeoning household debt : an islamic economic perspective. Journal of Scientific Research 12 (9): 1182-1189. doi: 10.5829/idosi.mejsr.2012.12.9.267

Hassan, S. K., \& Ahmad, S. (2005). Ekonomi islam. Kuala Lumpur. Dewan Bahasa dan Pustaka. Sulaiman, S. (2011). Portal Rasmi Muamalat \& Kewangan Islam. Kertas Ilmiah. Konsep Pinjaman Menurut Perspektif Islam. Putrajaya: Jabatan Kemajuan Islam Malaysia (JAKIM). 